\title{
Modelling soil nitrogen mineralisation in semi-mature pine stands of South Africa to identify nutritional limitations and to predict potential responses to fertilisation
}

\author{
Ben du Toit ${ }^{1}$ (D) Gerhardus Petrus Scheepers ${ }^{1}$ \\ Received: 14 June 2019 / Accepted: 20 January 2020 / Published online: 19 March 2020 \\ (C) INRAE and Springer-Verlag France SAS, part of Springer Nature 2020
}

\begin{abstract}
- Key Message Estimates of available nitrogen (based on topsoil nitrogen mineralisation rates) in semi-mature stands of Pinus radiata (D Don.) as well as pure species and hybrids of Pinus elliottii (Engelm.) in South Africa display a strong, significant, negative relationship with growth response to applied fertilisers in field experiments. This inexpensive technique can be incorporated in a fertiliser decision support system to minimise wasteful fertiliser applications.

- Context South African mid-rotation pine stands respond with high variability to nitrogen fertiliser supplements in the presence of phosphorus.

- Aims We aimed to find a screening tool for stands that are responsive to fertilisation.

- Methods The volume growth response relative to control plots (3 years after fertilisation with $200 \mathrm{~kg}^{-1} \mathrm{~N}$ in the presence of $100 \mathrm{~kg} \mathrm{ha}^{-1} \mathrm{P}$ ) was determined across 14 pine fertiliser experiments in South Africa. These values were correlated to soil and other properties for each site and also to estimates of $\mathrm{N}$ availability and $\mathrm{N}$ mineralisation rates using the Soil Nitrogen Availability Predictor (SNAP) model.

- Results The relative volume growth response to fertilisation ranged with a factor from 0.05 to 0.96 . No single result from standard soil analyses showed a strong positive or negative correlation with this growth response. However, highly significant negative correlations were observed between an estimate of $\mathrm{N}$ availability based on topsoil aerobic nitrogen mineralisation rates and the relative volume growth responses to fertilisation.

- Conclusion The estimate of $\mathrm{N}$ availability derived from incubation studies may assist us to predict the magnitude of the response to $\mathrm{N}$ fertilisation (in the presence of $\mathrm{P}$ ) with a fair degree of accuracy. The accuracy can be improved if the $\mathrm{N}$ availability estimate from aerobic incubation is used with other variables ( $\mathrm{pH}$ and soil $\mathrm{C}$ content) in a multivariate regression to predict relative yield response to fertilisation.
\end{abstract}

Keywords Slash pine $\cdot$ Monterey pine $\cdot$ Nitrogen mineralisation $\cdot$ Site-specific fertiliser applications

\section{Handling Editor: David Drew}

Contributions of the co-authors Ben du Toit conceptualised the two series of research trials in the Boland and Tsitsikamma regions, he procured funding for the work, and supervised three technical assistants plus six postgraduate students who contributed technical support to produce the basic data sets that constitute the building blocks for this paper. GP Scheepers conducted the experimental series in the Tsitsikamma region. He also modelled $\mathrm{N}$ availability with the SNAP model for both regions and did the statistical analyses. The two authors contributed roughly equal portions to the writing, reviewing and editing of the manuscript.

This article is part of the topical collection on Frontiers in Modelling Future Forest Growth, Yield and Wood Properties

\section{Ben du Toit}

ben@sun.ac.za
Gerhardus Petrus Scheepers

gps.geeps@gmail.com 


\section{Introduction}

Pine plantations growing in warm climates commonly respond to applications of $\mathrm{N}$, and often, the responses are maximal when combined with $\mathrm{P}$ and/or additional nutrients (Donald et al. 1987; Payn et al. 1988; Vose and Allen 1988; Turner et al. 1996; Fife and Nambiar 1997; Carlson and Soko 2000; Campion and du Toit 2003; Albaugh et al. 2004; Fox et al. 2007). However, not all stands respond with significant growth improvements when fertilised, as other resources may be limiting growth, or alternatively, growth may already be close to optimum rates obtainable under ambient climatic conditions. Knowing (a) which sites will respond to added fertilisers and (b) whether both $\mathrm{N}$ and $\mathrm{P}$ have to be applied for optimum response are essential questions that need to be answered to make sound economic and environmentally responsible decisions on forest fertilisation (Fisher and Binkley 2000; du Toit 2006).

Nitrogen $(\mathrm{N})$ dynamics in forest systems are chiefly governed by three variables: water availability, temperature, and substrate quality (Paul et al. 2002, 2003). It follows that several factors indirectly affecting these three major variables may exert some influence on $\mathrm{N}$ availability. For example, $\mathrm{N}$ dynamics are significantly affected by climate, aspect, soil surface roughness (Smethurst et al. 2015), tree species, soil water availability (Knoepp and Swank 1998; Lee and Jose 2006; Arslan et al. 2010) and various soil properties, such as soil texture, organic matter content, soil $\mathrm{pH}$ and the $\mathrm{C} / \mathrm{N}$ ratio (Arslan et al. 2010; Pulito et al. 2015). Forest management practices, such as cultivation, forest floor removal, slash management practices, thinning and irrigation may also affect the net $\mathrm{N}$ mineralisation rates of a soil and subsequent $\mathrm{N}$ uptake by trees (O'Connel et al. 2004; du Toit and Dovey 2005; Smethurst et al. 2015). Nitrogen availability refers to the rate at which $\mathrm{N}$ is converted from unavailable to plant-available forms in the rooting zone (Binkley and Hart 1989). The ability to quantify $\mathrm{N}$ dynamics in the soil (and hence estimate the portion of $\mathrm{N}$ that is readily available for tree uptake) can contribute significantly to the improvement of accurate, sitespecific $\mathrm{N}$ fertiliser prescriptions in plantation forestry (Paul et al. 2003; Laclau et al. 2010; Smethurst et al. 2015). The SNAP model (Soil Nitrogen Availability Predictor) was developed by Paul et al. (2002) to predict $\mathrm{N}$ mineralisation rates in soils. Smethurst et al. (2015) evaluated the feasibility of using the SNAP model in tropical eucalypt plantations in Brazil and found that the predicted net $\mathrm{N}$ mineralisation rates were highly correlated to the actual measured rates of $\mathrm{N}$ mineralisation in field after 21 months. The authors used the model specifically to understand and predict $\mathrm{N}$ mineralisation rates in plantation forest soils and also recommended that the model be applied to a wider range of tropical and temperate conditions for this purpose.

The possibility of implementing the SNAP model or other estimates of $\mathrm{N}$ availability as fertilisation decision support in the softwood plantations of South Africa has yet to be investigated. On the southern seaboard of South Africa, most stands respond to added P (Payn et al. 1988; De Ronde 1992); however, some sites may respond to additional $\mathrm{N}$ in the presence of $\mathrm{P}$ (Donald et al. 1987; Chikumbu 2011). Significant advances can thus be made in forest fertilisation in these regions if the need for added fertiliser $\mathrm{N}$ is better understood. Conceptually, soils with inherently high rates of $\mathrm{N}$ mineralisation during the growing season are less likely to respond to $\mathrm{N}$ supplements in the form of fertilisation than soils that display low levels of $\mathrm{N}$ availability during $\mathrm{N}$ mineralisation assays. However, this has not been quantified under field conditions in South Africa. We therefore formulated and tested the following hypothesis: the estimates of soil $\mathrm{N}$ availability (obtained from soil incubation assays) are likely to be negatively correlated with the volume growth response to $\mathrm{N}$ fertiliser supplements in semi-mature pine stands and this relationship may improve our ability to predict a particular site's responsiveness to fertilisation. The experimental approach thus consisted of (i) doing aerobic incubation studies on soil samples under controlled (laboratory) conditions, (ii) calculating modelled estimates of $\mathrm{N}$ mineralisation rates representing field conditions (by using the SNAP model among other techniques) and (iii) correlating the modelled estimates in $\mathrm{N}$ mineralisation with the volume growth response to $\mathrm{N}$ fertilisers in mid-rotation pine fertiliser experiments.

\section{Material and methods}

\subsection{Site description}

Two series of fertiliser experiments on mid-rotation pines were established and monitored in the Western and Eastern Cape provinces of South Africa (hereafter collectively referred to as the Cape Forest Regions) during the last decade (Chikumbu 2011; Scheepers 2018). For the purposes of this paper, the data of these two separate experimental series have been combined to yield information on a total of 14 field experiments. Eight of these experiments were established in the Tsitsikamma region, Eastern Cape, at longitude $23-24^{\circ}$ East and latitude $33-34^{\circ}$ South during 2015. The climatic conditions and main soil groups (after Fey 2010), for these experiments, are listed in Table 1. Due to the prolonged waterlogging conditions that prevail in the majority of soil types in the Tsitsikamma, the preferred species is Pinus elliottii (or its hybrids). Mid-rotation stands of Pinus elliottii (Engelm.) and hybrids of Pinus elliottii $\times$ Pinus caribaea (Morelett) var. hondurensis (Barr \& Golf.) were thus used in the Tsitsikamma region experimental series (Table 1). 
Table 1 Field experiment characterisations for the Cape Forest Regions at time of treatment implementation

\begin{tabular}{|c|c|c|c|c|c|c|c|}
\hline Site & $\begin{array}{l}\text { Plantation and } \\
\text { compartment no. }\end{array}$ & Genotype & Stand age (years) & $\begin{array}{l}\text { Stand density } \\
\left(\text { trees }^{-1}{ }^{-1}\right)\end{array}$ & $\begin{array}{l}\text { Initial LAI } \\
\left(\mathrm{m}^{2} \mathrm{~m}^{-2}\right)\end{array}$ & Altitude (m) & $\begin{array}{l}\text { Broad soil } \\
\text { group (Fey 2010) }\end{array}$ \\
\hline A & Witelsbos (H6) & P. elliottii & 13 & 484 & 3.2 & 261 & Plinthic \\
\hline B & Witelsbos (B57b) & P. ell $x$ car & 13 & 533 & 3.8 & 162 & Plinthic \\
\hline $\mathrm{C}$ & Lottering (D8b) & P. elliottii & 14 & 409 & 4.9 & 233 & Cumulic \\
\hline $\mathrm{D}$ & Lottering (L67) & P. ell $x$ car & 15 & 444 & 4.6 & 231 & Plinthic \\
\hline $\mathrm{E}$ & Lottering (R28) & P. elliottii & 13 & 416 & 3.4 & 219 & Podzolic \\
\hline $\mathrm{F}$ & Lottering (L22a) & P. elliottii & 14 & 396 & 3.4 & 213 & Podzolic \\
\hline G & Lottering (C33d) & P. elliottii & 14 & 486 & 6.4 & 227 & Plinthic \\
\hline $\mathrm{H}$ & Lottering (L46b) & P. elliottii & 13 & 446 & 4.2 & 218 & Plinthic \\
\hline S1 & Grabouw (J27) & P. radiata & 15 & 393 & 1.5 & 342 & Hydromorphic \\
\hline S2 & Grabouw (D12) & P. radiata & 15 & 430 & 3.0 & 280 & Lithic \\
\hline S3 & Grabouw (E14) & P. radiata & 13 & 400 & 2.1 & 280 & Hydromorphic \\
\hline S4 & Kluitjieskraal (B7) & P. radiata & 14 & 407 & 4.0 & 269 & Cumulic \\
\hline L2 & Grabouw M13a) & P. radiata & 17 & 435 & 1.9 & 276 & Duplex \\
\hline L4 & Grabouw (G36a) & P. radiata & 16 & 413 & 3.8 & 394 & Cumulic \\
\hline
\end{tabular}

The remaining six field experiments were established in the Boland region, Western Cape, at longitude $18-19^{\circ}$ East and latitude $33-34^{\circ}$ south. Pinus radiata (D Don.) is the most suitable species in all but the poorest quality site types of the Boland region (given the Mediterranean-type climate), and it was thus the species chosen for the Boland experimental series (Table 1).

At the time of treatment implementation, all the selected sites were semi-mature, aged between 13 and 17 years, and had been subjected to a mid-rotation thinning. Large variations in soil physical and chemical properties, as well as litter layer depth, stand leaf area index and growth of understorey vegetation were observed among sites (Table 2).

\subsection{Experimental design and treatment implementation}

The two series of fertiliser experiments used a complete factorial design (Boland region) and an incomplete randomised block design (Tsitsikamma region), respectively, and both utilised the following fertiliser levels: $\mathrm{N}(0,100$ and $\left.200 \mathrm{~kg} \mathrm{ha}^{-1}\right)$ and $\mathrm{P}\left(0,50\right.$ and $\left.100 \mathrm{~kg} \mathrm{ha}^{-1}\right)$. The Boland series

Table 2 Selected soil properties of topsoil $(15 \mathrm{~cm})$ from each site

\begin{tabular}{|c|c|c|c|c|c|c|c|c|c|}
\hline Site & $\begin{array}{l}\text { Plantation and } \\
\text { compartment number }\end{array}$ & $\mathrm{pH}(\mathrm{KCl})$ & $\mathrm{C} \%$ & Total $N \%$ & Clay $\%$ & Silt \% & Sand \% & $\begin{array}{l}\text { Textural } \\
\text { classification }\end{array}$ & Soil depth $\mathrm{m}$ \\
\hline A & Witelsbos (H6) & 4.0 & 1.6 & 0.04 & 14.0 & 21.0 & 65.0 & SaLm & 4.0 \\
\hline B & Witelsbos (B57b) & 3.9 & 1.1 & 0.04 & 12.0 & 13.0 & 75.0 & SaLm & 1.2 \\
\hline $\mathrm{C}$ & Lottering (D8b) & 3.8 & 2.6 & 0.07 & 20.0 & 39.0 & 41.0 & SaLm & 2.2 \\
\hline $\mathrm{D}$ & Lottering (L67) & 3.8 & 2.3 & 0.08 & 18.0 & 39.0 & 43.0 & SaLm & 2.6 \\
\hline $\mathrm{E}$ & Lottering (R28) & 3.7 & 2.7 & 0.07 & 18 & 35.0 & 47.0 & SaLm & 2.0 \\
\hline $\mathrm{F}$ & Lottering (L22a) & 3.4 & 2.6 & 0.04 & 18.0 & 40.0 & 42.0 & SaLm & 1.2 \\
\hline G & Lottering (C33d) & 3.4 & 3.1 & 0.12 & 16.0 & 44.0 & 40.0 & SaLm & 1.6 \\
\hline $\mathrm{H}$ & Lottering (L46b) & 3.3 & 2.6 & 0.07 & 19 & 40.0 & 41.0 & SaLm & 3.2 \\
\hline S1 & Grabouw (J27) & 4.3 & 1.2 & 0.03 & 0.8 & 3.0 & 96.2 & $\mathrm{Sa}$ & 0.5 \\
\hline $\mathrm{S} 2$ & Grabouw (D12) & 3.4 & 7.0 & 0.36 & 0.8 & 0.8 & 98.4 & $\mathrm{Sa}$ & 0.6 \\
\hline S3 & Grabouw (E14) & 3.1 & 5.9 & 0.23 & 0.8 & 0.8 & 98.4 & $\mathrm{Sa}$ & 2.0 \\
\hline S4 & Kluitjieskraal (B7) & 4.2 & 5.3 & 0.20 & 2.4 & 0.4 & 97.2 & $\mathrm{Sa}$ & 2.0 \\
\hline L2 & Grabouw (M13a) & 4.1 & 1.6 & 0.05 & 1.2 & 4.4 & 94.4 & $\mathrm{Sa}$ & 0.6 \\
\hline L4 & Grabouw (G36a) & 3.7 & 5.9 & 0.31 & 8.0 & 26.0 & 66.0 & $\mathrm{LmSa}$ & 1.0 \\
\hline
\end{tabular}


originally consisted of four experiment sites on sandy soil profiles (designated as $\mathrm{S} 1-\mathrm{S} 4$ ), plus 4 sites with sandy topsoils overlying loamy subsoils (designated as L1-L4) (Chikumbu 2011). One experiment site (L3) was destroyed in a wildfire within months after establishment. Site L1 incurred some tree top damage after treatment and was eventually destroyed by fire 3 years after treatment. For these reasons, only six undamaged experiments from the Boland region were used in this paper. The Tsitsikamma fertiliser series had eight sites with two replications each designated A-H (Scheepers 2018).

Limestone ammonium nitrate (LAN) and concentrated superphosphate were used as $\mathrm{N}$ and $\mathrm{P}$ sources. The LAN fertiliser contained $28 \% \mathrm{~N}$ and $2 \% \mathrm{Ca}$. The phosphate blend contained $20 \% \mathrm{P}, 15 \% \mathrm{Ca}, 1.5 \% \mathrm{~S}$ and $0.5 \% \mathrm{Zn}$.

\subsection{Stand volume estimation}

Tree heights and diameters at breast height (dbh) were measured every 6 months for a period of 3 years after treatment. Tree volumes were estimated using the equations based on the Schumacher and Hall model (Bredenkamp 2012). These individual tree volumes of live trees were summed per plot and upscaled to units of $\mathrm{m}^{3} \mathrm{ha}^{-1}$. Mortality in both trial series was minimal, probably due to the fact that all plots underwent a thinning from below just prior to treatment implementation, which removed trees in suppressed and intermediate size classes. Survival across all trials in the Tsitsikamma region was $96 \%$ at 3 years after treatment; $2.5 \%$ of the reported mortality was from losing two plots to fire at site $\mathrm{G}$ in 2018 and the remaining $1.5 \%$ from baboon, wind and lightning damage. A mortality rate of only $0.07 \%$ was recorded for the six remaining experiments in the Boland region at 3 years after treatment. The volume growth response over a 3 -year period after treatment implementation in the highest fertiliser application treatment $\left(\mathrm{N}_{200} \mathrm{P}_{100}\right)$ was expressed as a relative volume growth improvement in excess of the unfertilised control treatment (hereafter relative yield) (du Toit and Scheepers 2020). This was done to standardise the growth response among the different species and sites to a common scale.

\subsection{Soil sampling and nutrient analyses}

Before fertilisation, six soil samples were collected per replication and bulked to produce a single sample for analysis. Soil samples were air-dried and sieved $(2 \mathrm{~mm})$ and the stone fraction was calculated for each experimental site. Soil $\mathrm{pH}$ was determined using $1 \mathrm{M} \mathrm{KCl}$ in a 1:2:5 soil/solution ratio and total $\mathrm{C}$ content was determined by means of high-temperature combustion, using a Leco Truspec ${ }^{\circledR} \mathrm{C}$ analyser. Textural fractions were determined by sifting each sample, after dispersion with a sodium-hexametaphosphate solution. Silt and clay contents were determined by using the sedimentation rates at $20{ }^{\circ} \mathrm{C}$ and an ASTM E100 (152H-TP) hydrometer. The soil water holding capacity was mathematically determined from the soil texture model of Saxton et al. (1986). Separate subsamples were transferred to the lab for aerobic incubation.

\subsection{Aerobic incubation and estimation of $\mathrm{N}$ mineralisation rates}

Nitrogen availability was determined by an adaptation of the methodology outlined by Vitousek et al. (1982). Freshly acquired soil samples were kept near field conditions for 2 days prior to preparation and analysis. Samples were wetted to approximate field capacity and allowed to drain for $48 \mathrm{~h}$ to ensure each soil was at field capacity at the start of the incubation period. Thereafter, moisture contents were kept at a constant level (i.e. near field capacity) throughout the incubation period by daily gravimetric modelling (Binkley and Vitousek 1989). Two 25-g (fresh weight) samples of soil from each site were placed in wide-mouth containers and weighed. At the same time, $10 \mathrm{~g}$ of each soil was extracted and analysed for $\mathrm{NH}_{4}^{+}$as a preincubation measurement. Several holes were pre-drilled into each container to allow aeration during incubation. Samples were incubated for 4 weeks at $39{ }^{\circ} \mathrm{C}$ (Tsitsikamma samples) and $30{ }^{\circ} \mathrm{C}$ (Boland region samples). Note that any incubation temperature at the higher end of the optimum temperature for microbial action (between ca. 20 and $40{ }^{\circ} \mathrm{C}$ ) can be used to determine the basal (or so-called normalised) $\mathrm{N}$ mineralisation rate in subsequent modelling. The laboratory mineralisation rate is normalised to yield a basal incubation rate, i.e. it is adjusted to the rate occurring at a temperature of $40{ }^{\circ} \mathrm{C}$ and a water content at field capacity (Paul et al. 2002). After the incubation period, $100 \mathrm{ml}$ of a $2 \mathrm{M} \mathrm{KCl}$ solution was used to extract each 10 -g sample. Each solution was shaken for $60 \mathrm{~min}$, the supernatant filtered and analysed for $\mathrm{NH}_{4}^{+}$and $\mathrm{NO}_{3}^{-}$, the sum of which was labelled as available N. Bremner (1965) suggested subtracting the available $\mathrm{N}$ before, from the available $\mathrm{N}$ after incubation; however, the balance between mineralisation and immobilisation by microbial biomass in soils with poor fertility may yield negative values and the process of restoring balance may not occur during short incubation periods. For this reason, two estimates of soil $\mathrm{N}$ availability were calculated: (1) the difference in available $\mathrm{N}$ before and after incubation (hereafter, net $\mathrm{N}$ mineralisation or NNM) and (2) a gross estimate of soil $\mathrm{N}$ availability, i.e. determining the total $\mathrm{NH}_{4}^{+}$and $\mathrm{NO}_{3}^{-}$after incubation without subtracting the available $\mathrm{N}$ levels present before incubation (hereafter, gross $\mathrm{N}$ availability estimate or GNA). The latter estimate has been recommended by Mariano 
et al. (2013), working on anaerobic N mineralisation studies in Brazil, because it improved the reliability of the estimate of mineralisable $\mathrm{N}$ in that study.

\subsection{SNAP model applied to soil horizons}

The SNAP model, developed by the CSIRO, Australia (Paul et al. 2002), was used to calculate the annual, modelled $\mathrm{N}$ mineralisation rates for each experimental site. The SNAP model uses a basal $\mathrm{N}$ mineralisation rate $(\mathrm{k})$, determined by normalisation of aerobic incubation tests in the laboratory that is subsequently adjusted through implementation of soil temperature $(\mathrm{Tm})$ and soil water $(\mathrm{Wm})$ modifiers to estimate $\mathrm{N}$ mineralisation under ambient field conditions. The SNAP model can be run for several soil layers or horizons that can be summed together to determine a field $\mathrm{N}$ mineralisation estimate at the cumulative depth of all the chosen horizons. We used a single 0-15-cm layer approach per hectare in the Tsitsikamma, but mineralisation rates for the $0-5$ - and 5-15$\mathrm{cm}$ horizons were determined separately in the Boland region as part of an earlier study. In order to compare mineralisation estimates and site-specific edaphic properties among experimental sites from both regions, these values had to be estimated for a depth of $0-15 \mathrm{~cm}$. This was done by multiplying mineralisation rates with the fractional mass per horizon and summing the result to represent the $0-15-\mathrm{cm}$ layer.

\subsection{SNAP model inputs}

The soil characterisation completed at the onset of the project provided most of the input data for the SNAP model. Additional input variables, such as daily radiation, air temperatures, soil moisture content, bulk density, canopy LAI, fractional canopy cover, fractional litter cover, fractional weed cover, litter layer mass and litter layer height were estimated separately. A visual classification was used to determine the fractional litter and weed cover estimates per field experiment. Leaf area index measurements were used to estimate the fractional canopy cover. Radiation, air temperature and precipitation data sets were acquired from the weather stations in close proximity to the experiment sites. Soil bulk density was determined from undisturbed soil cores.

Seasonal measurements of intercepted radiation under and outside the tree canopies were done (at 3- to 6-month intervals) and these estimates were used to interpolate LAI on a monthly basis. Several studies recommend the use of a correction factor to adjust optically recorded "plant area indices" to actual LAI estimates (Gower and Norman 1991; Chen and Cihlar 1995; Dovey and du Toit 2006; Lopes et al. 2016). The optical estimates obtained with an AccuPAR Ceptometer were thus multiplied with a correction factor of 1.38 to determine corrected LAI values (after Lopes et al. 2016).
A large metal ring sampler (diameter $30 \mathrm{~cm}$ ) was used to collect three litter samples from each field study site. At the same time, four litter depths were measured in the ring at $0^{\circ}$, $90^{\circ}, 180^{\circ}$ and $270^{\circ}$ with a metal pin and ruler. The oven dry litter mass per sample (expressed in $\mathrm{tha}^{-1}$ ) was then regressed on the average litter depth $(n=24)$. The litter layer depth was measured at an additional 24 points in each field study site and the average regression estimates for litter mass thus obtained was substituted into the SNAP model.

\subsection{Statistical analysis}

Soil incubation tests described in Sect. 2.5, together with the modelling of these data by the SNAP model (Sect. 2.7), thus yielded a total of 5 estimates of $\mathrm{N}$ availability and these are shown in Table 3 for clarity. Prior to formal statistical analyses, data sets were tested for normality using the Shapiro-Wilk test and normal probability plots. The effects of site and treatment on soil $\mathrm{N}$ mineralisation rates and on the standardised growth response over the unfertilised control treatments for each site were analysed using analysis of variance (ANOVA) statistics. A least significant difference $\left(\mathrm{LSD}_{5 \%}\right)$ was used to show any significant interaction among treatments if the F statistic was significant for the treatment effect. Variables, treatments and interactions with $p<0.05$ were reported as having statistical significance. In addition, the Pearson correlation $(r)$ was used to investigate relationships between pairs of variables (indicators of $\mathrm{N}$ availability and relative yield response to $\mathrm{N}$ fertiliser in the presence of $\mathrm{P}$ fertiliser).

Finally, multiple regression techniques were used to predict the relative yield following fertilisation, by regressing a single $\mathrm{N}$ mineralisation estimate at a time (Table 3 ) with a number of uncorrelated site- or soil-based variables (Tables 1, 2, 4 and 5) per experiment, according to the following protocol: (i) data was subjected to a factor analysis and candidate variables for testing in the multiple regression were all taken from different factors, meaning that they were relatively uncorrelated; (ii) best subset regressions with 1 to 4 variables were performed and we used the adjusted $R^{2}$ as criterion to select the most suitable subset, taking parsimony into consideration (du Toit and Scheepers 2020). Data analysis and graphical illustrations were completed using Statistica 12 and Sigma Plot 11 software.

\section{Results}

\subsection{N mineralisation rates (aerobic incubation)}

The available $\mathrm{N}$ measured in samples at initiation and again after 28 days of laboratory incubation is shown in Table 4.

In the Tsitsikamma region, sites $\mathrm{A}$ and $\mathrm{G}$ had the highest NNM and GNA levels (Table 4). In the Boland region, the 
Table 3 Indicators of $\mathrm{N}$ availability used to correlate with the relative yield response to applied $\mathrm{N}$ fertiliser (in the presence of $\mathrm{P}$ fertiliser)

\begin{tabular}{lll}
\hline$\#$ & Variable name & Description \\
\hline 1 & Net N mineralisation & $\left(\mathrm{NH}_{4}^{+}+\mathrm{NO}_{3}^{-}\right.$after incubation) minus $\left(\mathrm{NH}_{4}^{+}+\mathrm{NO}_{3}^{-}\right.$before incubation) in sample \\
2 & Basal N mineralisation (BNM) & Variable \# 1, normalised to $40{ }^{\circ} \mathrm{C}$ and field water capacity (Paul et al. 2002) \\
3 & Modelled N mineralisation (MNM) & Variable \# 2, modelled over 1 year for ambient field conditions with SNAP \\
4 & Gross N availability estimate (GNA) & $\left(\mathrm{NH}_{4}^{+}+\mathrm{NO}_{3}^{-}\right)$after incubation in soil sample without any subtraction \\
5 & Normalised GNA & Variable \# 4, normalised to $40^{\circ} \mathrm{C}$ and field water capacity \\
\hline
\end{tabular}

${ }^{a}$ Note that we only present GNA values normalised to optimum temperature and moisture for the purpose of finding the variable that best describes the relative yield response and that we do NOT present GNA values that had been further modelled by SNAP for field conditions because the gross N mineralisation estimates, when modelled and upscaled, may overestimate the actual available $\mathrm{N}$ in field

highest NNM and GNA rates were observed at sites L4 and S2. The lower end of NNM and GNA values was observed for sites S1 and L2, where GNA values of 0.23 and $0.30 \mathrm{mg} \mathrm{N}$ $\mathrm{kg}^{-1}$ day $^{-1}$ were recorded.

\subsection{Normalised $\mathrm{N}$ mineralisation rates (basal rates)}

The basal $\mathrm{N}$ mineralisation rates (BNM and normalised GNA), calculated for the entire $0-15-\mathrm{cm}$ soil layer across all sites, are presented in Figs. 1 and 2. Mineralisation of $\mathrm{N}$ varied significantly among all sites $(p<0.001)$, with Tsitsikamma region having generally higher rates than the Boland Region, and with Boland region showing greater variation among sites (Table 5; Figs. 1 and 2).

\subsection{Fertiliser responses ( 3 years after treatment)}

In the Tsitsikamma region, modest to low responses to fertilisation with the highest application rates $\left(\mathrm{N}_{200} \mathrm{P}_{100}\right)$ were recorded (Fig. 3). Sites $\mathrm{H}$ and D were the most responsive in this region, with standardised relative volume growth responses of 0.20 and 0.16 , respectively (Fig. 3). Sites A, C and $\mathrm{E}$ were the least responsive, with values of $0.05,0.08$ and 0.09, respectively. In the Boland region, sites L2 and S1 were highly responsive to fertilisation, with increases in volume of 0.74 and 0.96 relative to the unfertilised control treatments.

\subsection{Relationships between $\mathrm{N}$ mineralisation rate, soil properties and growth responses to fertiliser}

\subsubsection{Indicators of $\mathrm{N}$ availability and edaphic properties}

The indicators of $\mathrm{N}$ availability were correlated against edaphic properties in an attempt to understand the response mechanisms and to identify useful indicators (Table 6). The only significant relationships were observed in the Boland region and across the combined trial series:

Table 4 Measured total $\mathrm{NH}_{4}^{+}$and $\mathrm{NO}_{3}^{-}$concentrations before and after 28 days of incubation with net $\mathrm{N}$ mineralisation and gross $\mathrm{N}$ availability estimates calculated

\begin{tabular}{|c|c|c|c|c|c|}
\hline Site & $\begin{array}{l}\text { Soil depth } \\
\mathrm{cm}\end{array}$ & $\begin{array}{l}\mathrm{NH}_{4}^{+}+\mathrm{NO}_{3}^{-} \text {(before incubation) } \\
\mathrm{mg}(\mathrm{kg} \text { topsoil })^{-1}\end{array}$ & $\begin{array}{l}\mathrm{NH}_{4}^{+}+\mathrm{NO}_{3}^{-} \text {(after incubation) } \\
\mathrm{mg}(\mathrm{kg} \text { topsoil })^{-1}\end{array}$ & $\begin{array}{l}\text { Net } N \text { mineralisation } \\
\mathrm{mg} \mathrm{N}(\mathrm{kg} \text { of topsoil })^{-1} \mathrm{day}^{-1}\end{array}$ & $\begin{array}{l}\text { Gross } N \text { availability estimate } \\
\text { mg } N(\text { kg of topsoil })^{-1} \text { day }^{-1}\end{array}$ \\
\hline A & $0-15$ & 26.0 & 55.0 & 1.04 & 1.96 \\
\hline B & $0-15$ & 38.0 & 45.0 & 0.25 & 1.61 \\
\hline $\mathrm{C}$ & $0-15$ & 24.8 & 36.4 & 0.41 & 1.30 \\
\hline D & $0-15$ & 31.6 & 42.2 & 0.38 & 1.51 \\
\hline E & $0-15$ & 23.6 & 39.0 & 0.55 & 1.39 \\
\hline $\mathrm{F}$ & $0-15$ & 23.6 & 34.2 & 0.38 & 1.22 \\
\hline G & $0-15$ & 25.2 & 63.8 & 1.38 & 2.28 \\
\hline $\mathrm{H}$ & $0-15$ & 25.4 & 36.4 & 0.39 & 1.30 \\
\hline S1 & $0-15$ & 3.17 & 6.53 & 0.12 & 0.23 \\
\hline S2 & $0-15$ & 24.3 & 31.4 & 0.25 & 1.12 \\
\hline S3 & $0-15$ & 5.60 & 12.6 & 0.25 & 0.45 \\
\hline S4 & $0-15$ & 3.55 & 13.3 & 0.35 & 0.47 \\
\hline L2 & $0-15$ & 3.92 & 8.40 & 0.16 & 0.30 \\
\hline L4 & $0-15$ & 15.1 & 19.8 & 0.17 & 0.71 \\
\hline
\end{tabular}



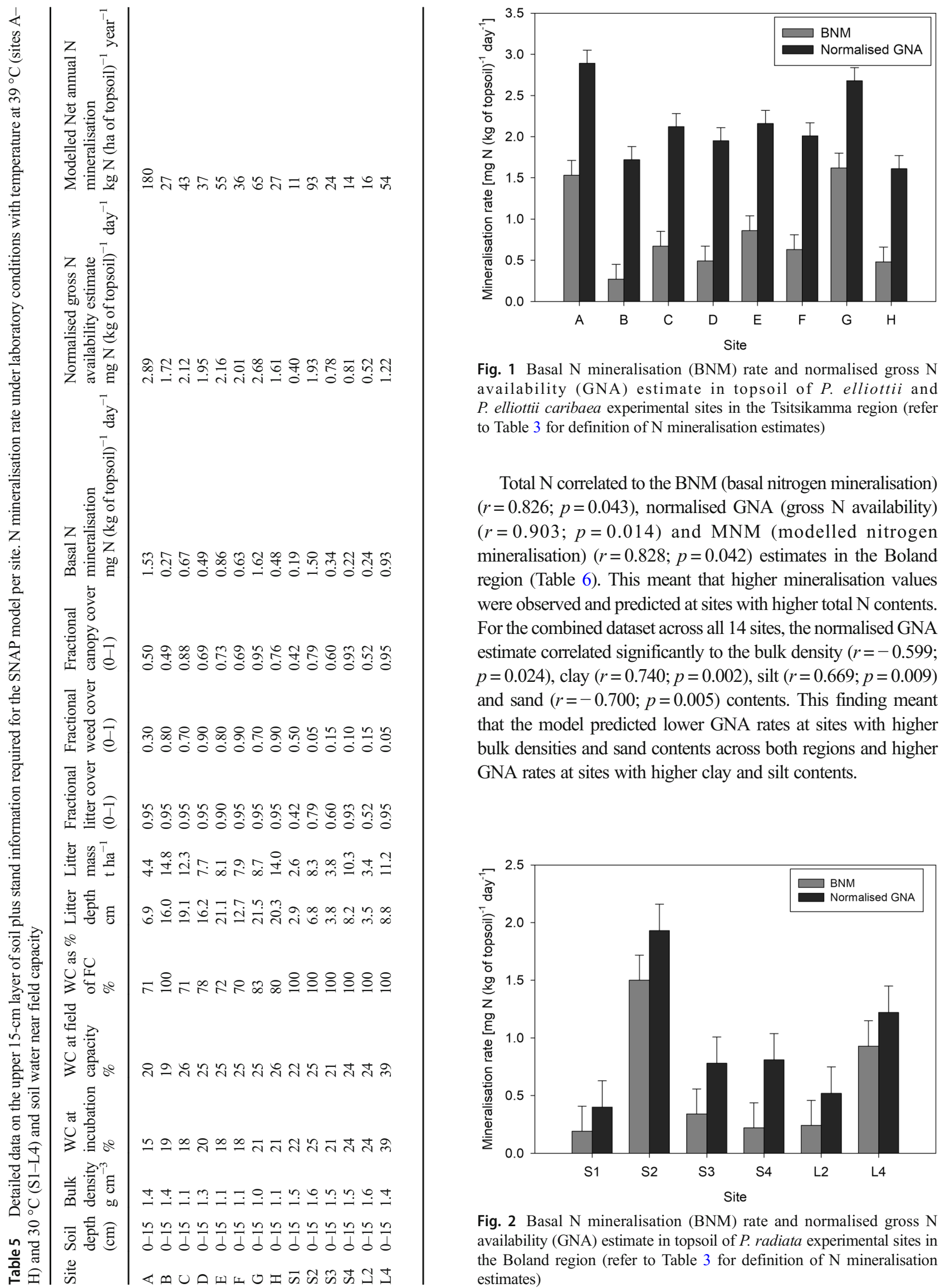

Fig. 1 Basal $\mathrm{N}$ mineralisation (BNM) rate and normalised gross $\mathrm{N}$ availability (GNA) estimate in topsoil of P. elliottii and $P$. elliottii caribaea experimental sites in the Tsitsikamma region (refer to Table 3 for definition of $\mathrm{N}$ mineralisation estimates)

Total $\mathrm{N}$ correlated to the $\mathrm{BNM}$ (basal nitrogen mineralisation) ( $r=0.826 ; p=0.043$ ), normalised GNA (gross $\mathrm{N}$ availability) $(r=0.903 ; p=0.014)$ and MNM (modelled nitrogen mineralisation) $(r=0.828 ; p=0.042)$ estimates in the Boland region (Table 6). This meant that higher mineralisation values were observed and predicted at sites with higher total $\mathrm{N}$ contents. For the combined dataset across all 14 sites, the normalised GNA estimate correlated significantly to the bulk density $(r=-0.599$; $p=0.024)$, clay $(r=0.740 ; p=0.002)$, silt $(r=0.669 ; p=0.009)$ and sand $(r=-0.700 ; p=0.005)$ contents. This finding meant that the model predicted lower GNA rates at sites with higher bulk densities and sand contents across both regions and higher GNA rates at sites with higher clay and silt contents.

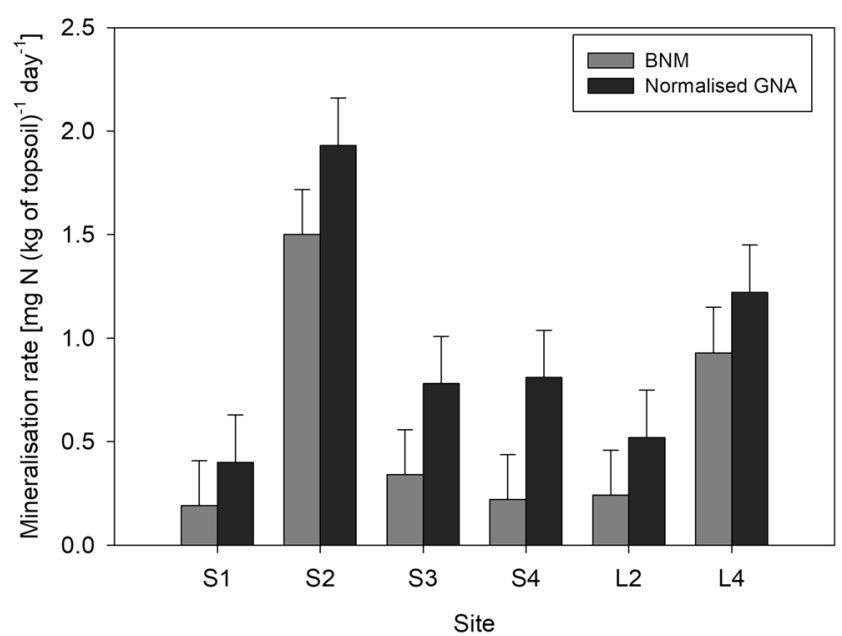

Fig. 2 Basal $\mathrm{N}$ mineralisation (BNM) rate and normalised gross $\mathrm{N}$ availability (GNA) estimate in topsoil of $P$. radiata experimental sites in the Boland region (refer to Table 3 for definition of $\mathrm{N}$ mineralisation estimates) 


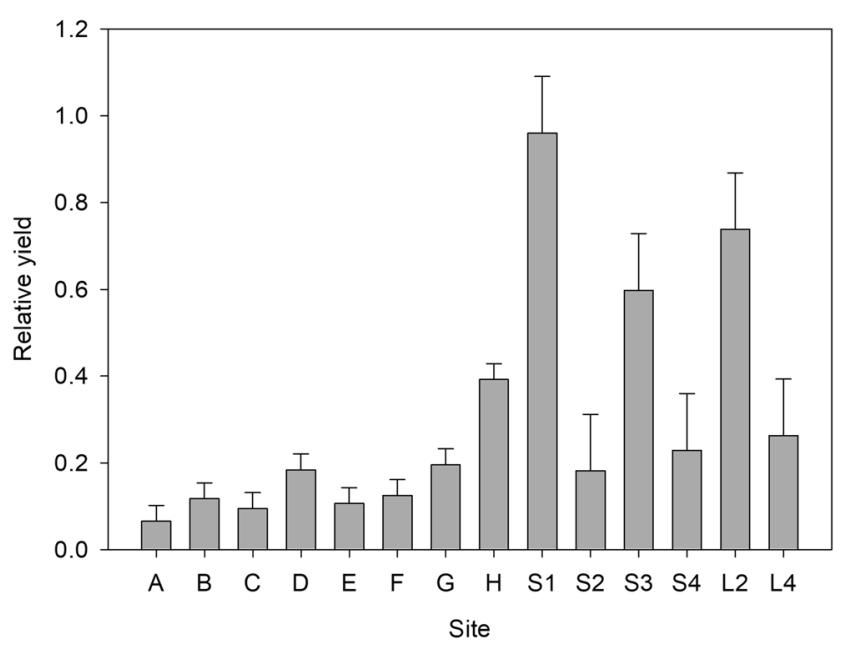

Fig. 3 Volume growth response to fertilisation with $200 \mathrm{~kg} \mathrm{~N}$ and $100 \mathrm{~kg}$ $\mathrm{P}$ per ha in pine stands relative to the unfertilised control treatments (relative yield) among combined experimental sites of the Cape Forest Regions

\subsubsection{Indicators of $\mathrm{N}$ availability and volume responses to fertilisation}

No significant correlation was found between BNM and relative yield response to $\mathrm{N}$ fertilisation within individual regions or when analysing the combined dataset across regions (Table 6). Further modelling with temperature and available water under ambient conditions in the plantation yielded the MNM estimate. The relationship between MNM and the relative yield response to $\mathrm{N}$ fertilisation was not significant within individual regions. This relationship improved when both datasets were combined; however, the Pearson correlation remained non-significant $(r=-0.492, p=0.074$ (Table 6 and Fig. 4).

No significant correlations were observed between the normalised GNA and the relative yield response in the Tsitsikamma region on its own (Table 6). However, in the Boland region, normalised GNA showed a much stronger relationship with relative fertiliser yield response, but it was still not significant $(r=-0.795, p=0.059)$ (Table 6). The relationship between the normalised GNA and relative yield was strong and significant $(r=-0.813 ; p<0.001)$ (Fig. 5 and Table 6$)$ for the combined $0-15$-cm layer across all 14 sites, at 3 years after fertilisation (Table 6 and Fig. 5).

The best subset regression [using normalised GNA, pH $(\mathrm{KCl})$ and topsoil $\mathrm{C}$ contents] is shown in Table 7 . The relative yield response to fertilisation with $\mathrm{N}$ in the presence of $\mathrm{P}$ (as observed in all 14 field trials) was plotted as a function of the predicted yield response (as obtained from the multiple regression output shown in Table 7), and the result (with confidence intervals) is shown in Fig. 6, with a 3D representation in Fig. 7.

\section{Discussion}

To ascertain whether estimates we obtained for the rate of $\mathrm{N}$ mineralisation in the incubation process and rate of $\mathrm{N}$ mineralisation modelled for field conditions fell within plausible and realistic ranges, we made a number of comparisons from the literature for comparable sites.

\subsection{The net and gross basal $\mathrm{N}$ mineralisation rates}

The net $\mathrm{N}$ mineralisation rate in soil samples from our experiment sites ranged from 0.01 to $1.96 \mathrm{mg} \mathrm{N} \mathrm{kg}^{-1}$ day $^{-1}$. Values obtained in comparable forest systems (all in $\mathrm{mg} \mathrm{N}$ $\mathrm{kg}^{-1}$ day $^{-1}$ ) are Carlyle et al. (1998), who obtained values between 0.02 and 0.53 in Pinus radiata stands of South Australia, Tasmania and Victoria. Tecimen and Kavgaci (2011) recorded values between 0.02 and 0.30 in 2- to 25year-old stands of Pinus brutia in Turkey. We calculated an average value of $0.09 \mathrm{mg} \mathrm{N} \mathrm{kg}^{-1}$ soil from Saggar et al. (2001), recorded among several stand density treatments under $P$. radiata in New Zealand. The range measured in the Cape Forest Regions partially overlaps and also exceeds the higher end of the range of published observations in comparable ecosystems. It is important to keep in mind that incubation temperatures in our study sites were higher than most of the comparisons cited above. According to Paul et al. (2002), incubations at $20{ }^{\circ} \mathrm{C}$ will yield on average only $27 \%$ of the incubation value at $40{ }^{\circ} \mathrm{C}$. It is therefore not surprising that some of our values exceed the higher end of the range cited.

The BNM and normalised GNA rates showed considerable variation among experimental sites (Table 5). This wide range obtained for BNM and GNA, coupled with the fact that response to fertilised over control treatments is available, makes it a highly suitable data set to study the usefulness of indicators of $\mathrm{N}$ response in pine plantations. It appears that the wide range in basal mineralisation rates is the major driver for the wide range of outputs obtained for modelled annual $\mathrm{N}$ mineralisation values (Table 5). The range in basal $\mathrm{N}$ mineralisation rates may stem from the highly variable edaphic conditions across the Cape Forest Regions (variable microbial populations, variable soil types, the wide ranges found in soil texture, topsoil organic $\mathrm{C}$ and soil $\mathrm{pH}$ ) and even manifests as the variable growth rate observed in the untreated control plots across the two regions (Tables 1 and 2; Scheepers 2018; Fischer and du Toit 2019). Variability among soil types thus seems to be the major driver of modelled $\mathrm{N}$ mineralisation rates; apparently, it has similar or greater leverage on the final modelled $\mathrm{N}$ mineralisation rate than the climatic conditions prevailing on sites. Basal mineralisation rates also allowed us to explore whether $\mathrm{N}$ mineralisation potential was strongly governed by particular characteristics or drivers inherent to the soil type (because basal rates have been normalised to a common temperature and water availability level). It appears that 
กิกิ กิ eे $\stackrel{0}{e}$ ㅎํㅇ ฉ i 1 i 1 क $\approx \hat{\infty} \approx$ 范 胥 ते

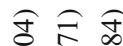
这 남 तิ $\frac{2}{0}$ तิ $\widehat{\circ}$ 过 กิ กิ

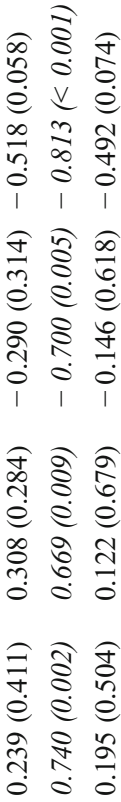

สิธิ์ $\stackrel{\infty}{e} \hat{e}$ 은 :

สู

อे ङ

于 aे

ปै กิ ๆ

ฟิ

용

๗ิ $\cong \approx$

สิ

กิ

ֻุ

กิ

웅

ลิ สิ

ㄹ

๙

के

กै

กุ

in

$\dot{0} 00$

ક $\overparen{Ð}$

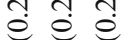

ฟิ ชู బ

กั กั ?

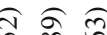

๗ิ กิ

กै กิ

100

$\frown$

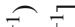

蛋

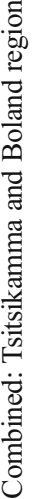

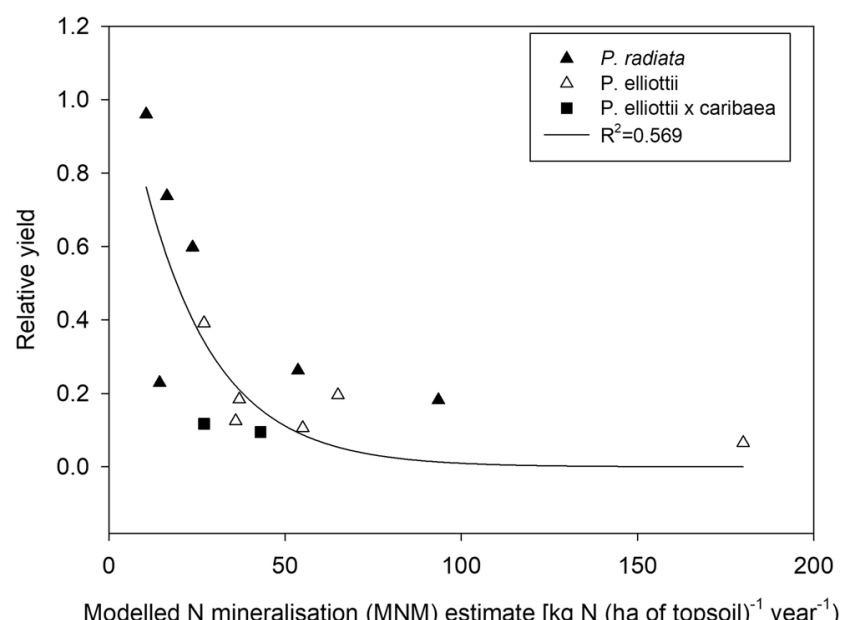

Fig. 4 Relationship between the modelled topsoil $\mathrm{N}$ mineralisation estimate (MNM) and the relative yield for the combined experimental sites of the Cape Forest Regions, 3 years after treatment

only total topsoil $\mathrm{N}$ content is moderately well correlated to basal $\mathrm{N}$ mineralisation rates within individual regions (Table 6). However, several of these relationships were strongly region-specific and did not hold when investigating the combined results for the two regions. Only after estimates were normalised to a common temperature and water availability level, did we observe significant correlations between several soil textural and bulk density variables versus the normalised GNA estimate (Table 6 and Sect. 3.4.1). We conclude that soil $\mathrm{N}$ mineralisation rates are probably governed by a number of different edaphic properties, each with a fairly substantial leverage on the magnitude of the process. It may be the reason why $\mathrm{N}$ mineralisation cannot be accurately predicted from a single edaphic factor, such as $\mathrm{pH}$, clay content or organic carbon content across the range of site conditions tested (Table 6).

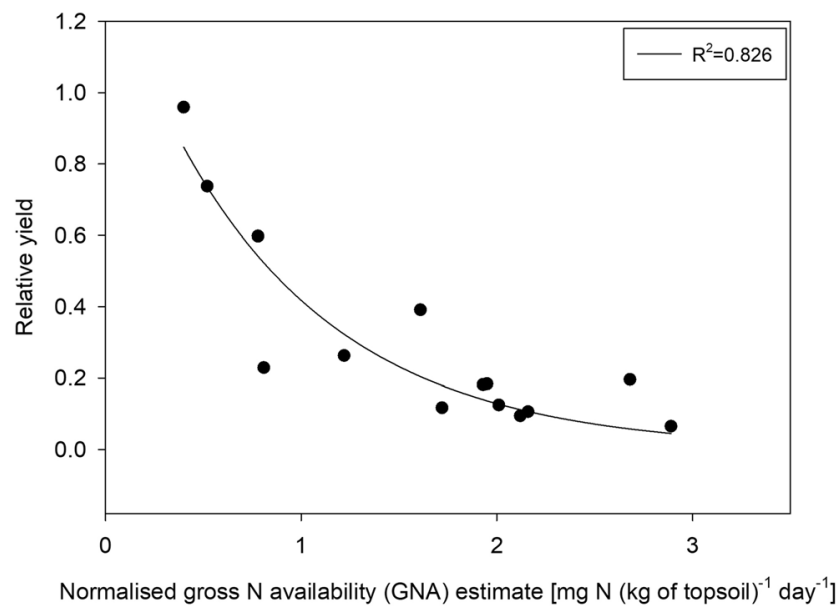

Fig. 5 Relationship between the normalised gross $\mathrm{N}$ availability estimate (normalised GNA) and relative yield for the combined experimental sites of the Cape Forest Regions, 3 years after treatment 
Table 7 Coefficients for soil factors in the multiple regression (b) to predict relative yield to fertilisation and their respective standard errors and $p$ values (significant values in italics). Dependent variable $=$ relative yield; $R^{2}=0.75$; adjusted $R^{2}=0.68 ; F(3,10)=10.051 ; p<0.0231$

\begin{tabular}{lllllr}
\hline Variable & $b^{*}$ & Std. error of $b^{*}$ & $b$ & Std. error of $b$ & $\mathrm{t}(10)$ \\
\hline Intercept & & & 1.606912 & 0.653 & $p$ value \\
$\mathrm{pH}(\mathrm{KCl})$ & -0.215705 & 0.196 & -0.162507 & 0.148 & 0.0341 \\
Organic C & -0.359467 & 0.189 & -0.050457 & 0.027 & -1.09912 \\
Normalised GNA & -0.935814 & 0.177 & -0.328131 & 0.062 & -1.89874 \\
\hline
\end{tabular}

\subsection{Modelled $\mathrm{N}$ mineralisation rates under ambient field conditions}

The predicted net annual soil $\mathrm{N}$ mineralisation rates within the $0-15-\mathrm{cm}$ topsoil layers reported in this study showed very high values for one site only, namely $180 \mathrm{~kg} \mathrm{~N} \mathrm{ha}^{-1}$ year $^{-1}$ in site $\mathrm{A}$ (Table 5). The rate in the remaining sites ranged from 10 to $111 \mathrm{~kg} \mathrm{~N} \mathrm{ha}^{-1}$ year $^{-1}$. Net $\mathrm{N}$ mineralisation rates modelled for the Cape Forest Regions largely overlapped with ranges of the values reported by comparable studies (all reported in $\mathrm{kg} \mathrm{N} \mathrm{ha}^{-1}$ year $^{-1}$ for 0-15-cm deep soil layers) viz. 16-74 in Australian pine plantations (Carlyle et al. 1998) an average of 40 in Mediterranean climate pine stands (Arslan et al. 2010), 24 in boreal scots pine stands (Pajuste and Frey 2003), 75 in sub-tropical pines in Florida, USA (Lee and Jose 2006), 38-50 in a clear felled South African eucalypt plantation site where slash was burnt or retained in situ (Dovey and du Toit 2015) as well as two reports for E. globulus stands in western Australia: 81-109 in red earth soils and levels of $54-78 \mathrm{~kg} \mathrm{~N} \mathrm{ha}^{-1}$ year $^{-1}$ in grey sands (O'Connel et al. 2004). To put the net $\mathrm{N}$ mineralisation numbers in context of other major $\mathrm{N}$ input-output fluxes recorded in South African plantation forest systems, du Toit and Scholes (2002) and Dovey et al. $(2011,2014)$ listed the following approximate $\mathrm{N}$ input/output rates, namely atmospheric deposition ranging from 15 to 19 , annualised losses due to slash burning operations from 11 to 17 and annualised leaching rates ranging from 1 to $4 \mathrm{~kg} \mathrm{ha}^{-1} \mathrm{year}^{-1}$. Annually mineralised $\mathrm{N}$ is thus the major contributor to supply readily available $\mathrm{N}$ to trees in warm climate plantation forest systems (most definitely in those systems without symbiotic N-fixing species present).
Fig. 6 Relationship between the multiple regression estimate for relative yield (predicted by normalised GNA, topsoil $\mathrm{C}$ and $\mathrm{pH})$ and the relative yield observed in field trials, 3 years after treatment for the combined experimental sites in the Cape Forest Regions

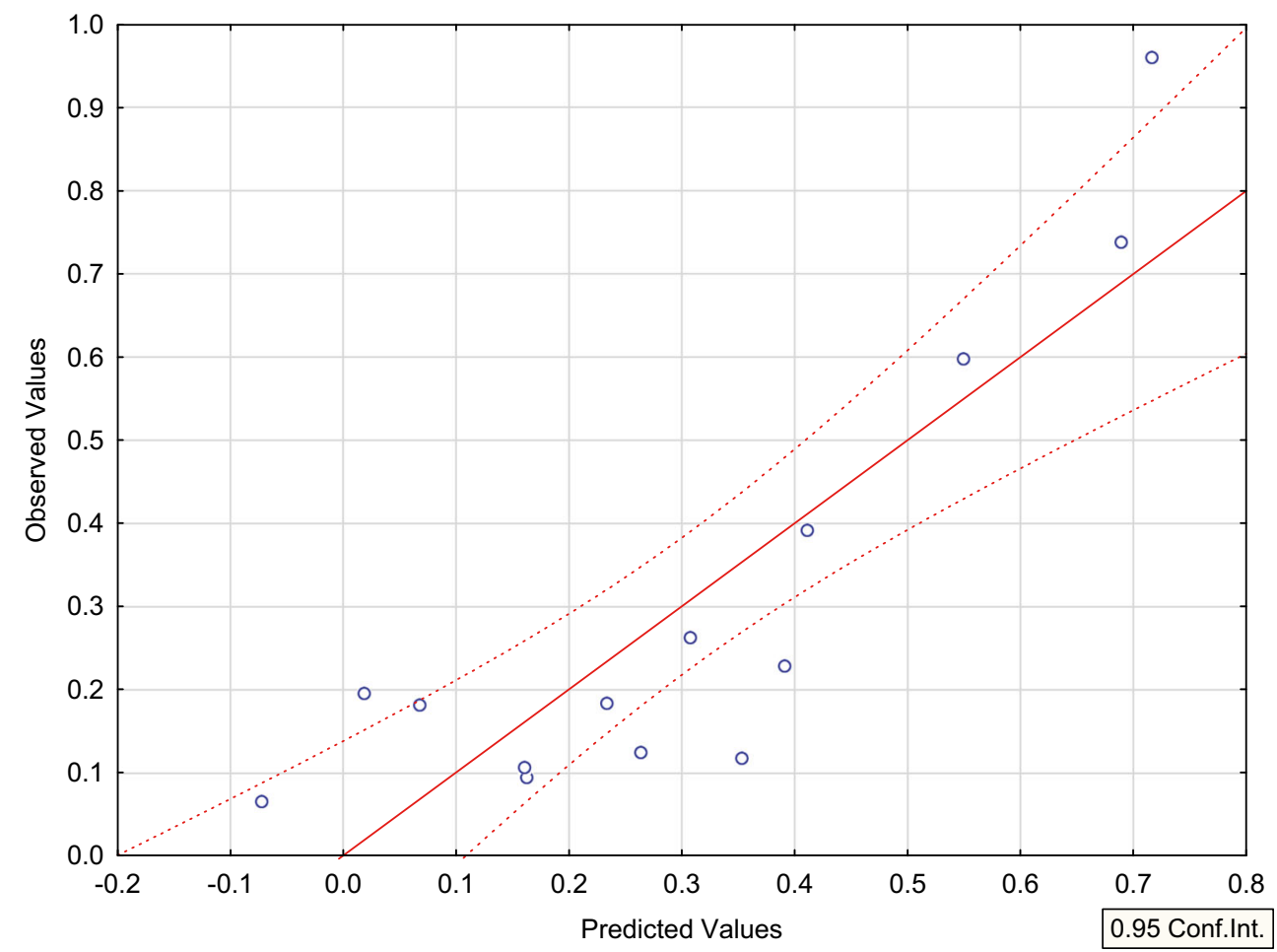


Site A had one of the higher $\mathrm{pH}(\mathrm{KCl})$ values among soils in our study with a well-drained sandy loam texture in the upper horizons (Table 2). This is combined with an extremely deep subsoil (Table 1) on a footslope position where it receives additional water flowing laterally from upslope positions (signs of periodic wetness are only visible in the subsoil below $0.60 \mathrm{~m}$ ). These characteristics, plus a moderately open canopy after thinning (Table 1), allowing for higher soil temperatures, have apparently contributed to elevated $\mathrm{N}$ mineralisation rates recorded at site A. Among the Boland experiments, sites S2 and L4 stood out as having moderately high $\mathrm{N}$ mineralisation rates (Fig. 2). Both these soils have high carbon and $\mathrm{N}$ concentrations in the topsoil (Table 2), and this may explain their relatively high fertility. Site S1 had the lowest modelled $\mathrm{N}$ mineralisation rate (by far). It is a shallow, hydromorphic sand that supported a stand with a very poor growth rate and low leaf area index before treatment implementation (Tables 1 and 2; Chikumbu 2011). Furthermore, it is situated in a location with fairly low precipitation in the Mediterranean-type climate zone, meaning that it will be very dry during summer but that it may also suffer from waterlogging for protracted periods of time in winter (as can be deduced from the soil type), which may even lead to some level of denitrification under field conditions (Sirivedhin and Gray 2006; Hamonts et al. 2013).

\subsection{Responsiveness to fertilisation}

All of the field experiments in our study responded positively to fertilisation when compared to their respective unfertilised control plots; however, there were different degrees of responsiveness. The relative volume growth response over the unfertilised control ranged from a factor of approximately 0.05 to 0.96 (Fig. 3). Furthermore, only a sub-set of the highly responsive sites showed statistically significant responses. Note that the fertilisation treatment referred to in this paper is $\mathrm{N}_{200} \mathrm{P}_{100}$. Strong responses to fertilisation of selected midrotation pine stands have been reported in many countries (Donald et al. 1987; Turner et al. 1996; Albaugh et al. 1998; Carlson and Soko 2000; Campion and du Toit 2003; Fox et al. 2007; Chikumbu 2011; Kotze and du Toit 2012; Campoe et al. 2013). However, the profitability of fertiliser application to a given site is chiefly governed by three factors: volume growth response to fertilisation, sawlog price and the interest rate (Knott et al. 1996). Estimating the growth response among different sites is clearly the most difficult value to obtain. It

\section{Model: Relative yield $=-0.328131^{*}$ Normalised GNA $-0.050457^{*}$ topsoil $\mathrm{C}-0.162507^{*} \mathrm{pH}(\mathrm{KCl})+1.606912$}

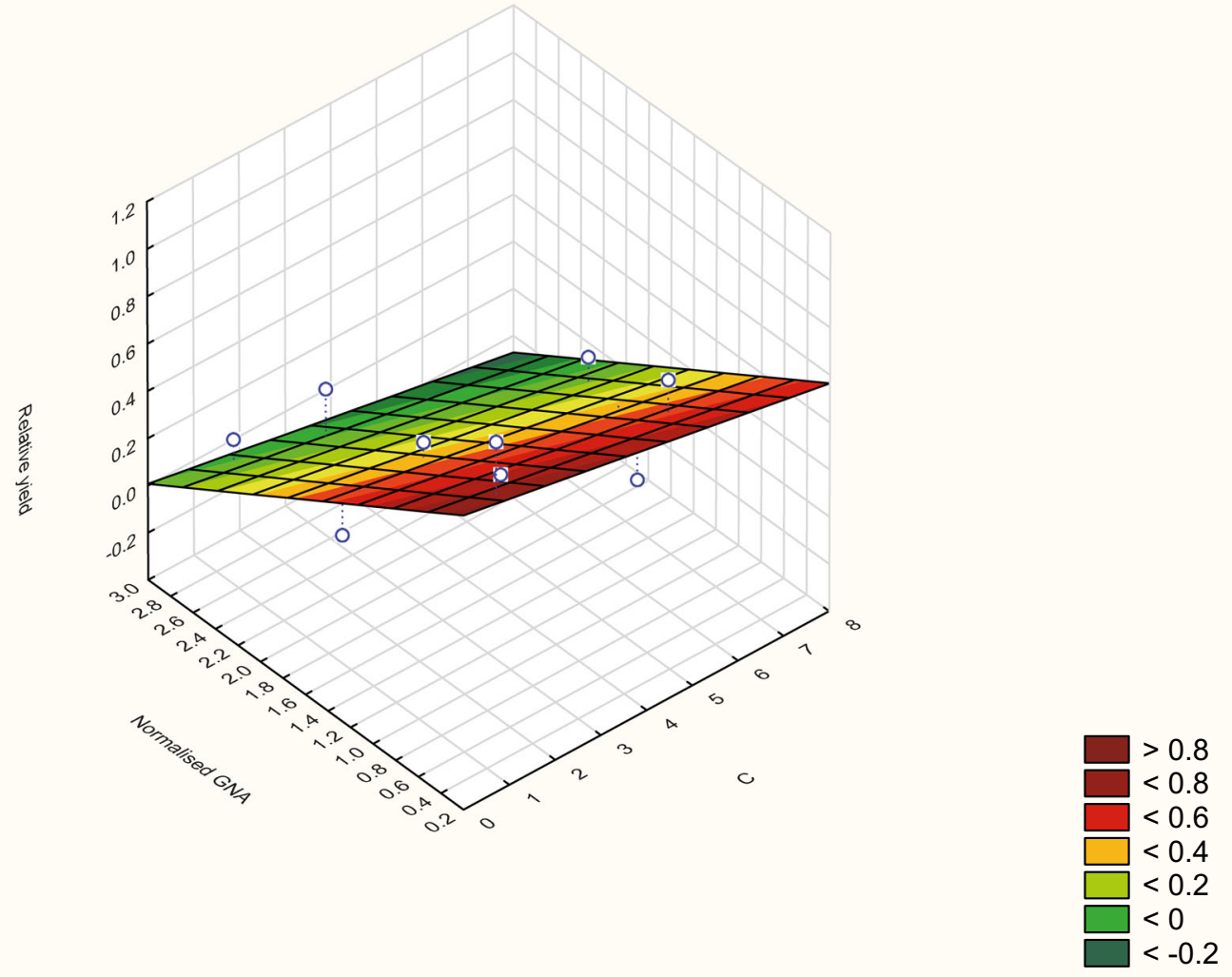

Fig. 7 Three-dimensional representation of the multiple regression estimate of relative yield response to fertilisation in the Cape Forest Regions [only the effect of the two most important input variables on relative yield (normalised GNA and topsoil C) are shown on the 3D plot; measurement units of normalised GNA is mg N per kg of topsoil per day and measurement units for topsoil $\mathrm{C}$ is \%] 
is critically important for the forest practitioner to acknowledge that the response to fertiliser application may be extremely variable among sites and that this problem has to be tackled, even if it means using decision support systems reliant on what Fisher and Binkley (2000) calls "imperfect information". Highly variable response rates to applied fertiliser across site types within many different regions of Southern Africa have been observed in mid-rotation pines (Donald et al. 1987; Morris 1995; Carlson and Soko 2000; Campion and du Toit 2003; du Toit 2006; Kotze and du Toit 2012). The reason for this phenomenon is often related to the availability of various other growth resources such as (1) available soil water, (2) climatic conditions, (3) one or more nutrient elements that are in relatively short supply in the soil, but were not included in the applied fertiliser blend, or (4) understorey vegetation that compete for nutrient uptake. According to Scheepers (2018), N and P may be the main limiting nutrients in the Tsitsikamma region, but moderately low concentrations of foliar $\mathrm{Fe}, \mathrm{Cu}$ and $\mathrm{B}$ have also been recorded sporadically in some plots. In the Boland Region, only N and P showed consistently low foliar levels across all trials. Marginal levels of K ( 2 trials) and $\mathrm{Zn}$ (one trial) were recorded, but not critically deficient levels (Chikumbu 2011). The nutrients with marginal levels in both regions may become more diluted following growth responses to fertilisation.

It must also be kept in mind that there are likely to be a number of site types in any given region that are sufficiently fertile to supply the bulk of the stand's nutritional demands. It is therefore very important to screen sites before fertiliser applications are planned and to select only those sites that are responsive to added fertilisers.

The most important question that needs to be answered is whether site or stand variables and/or the modelled outputs can assist us to predict the potential response to fertilisation. These variables can range from simple soil chemical or site properties (as presented in Table 2) or more complex, modelled outputs, such as the BNM, MNM or the normalised GNA. The usefulness of simple variables as predictors of site responsiveness to fertilisation is limited, as discussed above. We therefore focus our attention on the more complex predictors (involving incubation studies and subsequent normalisation or modelling), i.e. those predictors that integrate several factors to determine $\mathrm{N}$ supply.
The BNM and MNM estimates in this study were inferior predictors of site responsiveness relative to the normalised GNA estimates; however, it has potential for further investigation in other regions. One reason for the fact that MNM did not yield an improvement in predictive ability over the BNM may be that the Tsitsikamma plateau, where 8 of the trials are situated, has limited variation in climate conditions (although it does have fair variation in soil types). Site A (with very high MNM and GNA) gave the poorest response to $\mathrm{N}$ fertiliser of all the Tsitsikamma region sites (Fig. 3). In strong contrast, sites S1, S3 and L2 (Boland region) recorded very large improvements in growth with fertilisation (Fig. 3). These were also the sites that inherently have very low levels of available $\mathrm{N}$ due to retarded rates of $\mathrm{N}$ mineralisation (Fig. 5). The normalised GNA in the $0-15-\mathrm{cm}$ layer (combined data across both regions) shows a highly significant correlation with relative yield response (Fig. 5) It appears that sites with normalised GNA rates in the $0-15-\mathrm{cm}$ topsoil below $0.8 \mathrm{mg} \mathrm{N}$ ( $\mathrm{kg}$ of topsoil) ${ }^{-1}$ day $^{-1}$ are all highly responsive to added $\mathrm{N}$ fertilisation in the presence of phosphorus. In contrast, sites with high normalised GNA values were not responsive to fertilisation with N. Pulito et al. (2015) also observed poor growth responses to $\mathrm{N}$ fertilisation in sandy soils that had high $\mathrm{N}$ mineralisation rates.

The multiple regression using relatively uncorrelated variables (normalised GNA, topsoil $\mathrm{C}$ and $\mathrm{pH}$ in $\mathrm{KCl}$ ) improved our predictive ability for relative yield response to applied fertiliser $\left(R^{2}=0.751\right.$; Figs. 6 and 7$)$. The GNA is closely related to a combination of the available $\mathrm{N}$ levels in soil plus mineralised $\mathrm{N}$ following incubation, i.e. a classic estimator of nutrient flux rates, rather than pool sizes. In contrast with this, the topsoil $\mathrm{C}$ content is related to the total pool of $\mathrm{N}$ the specific soil layer and thus relatively uncorrelated with GNA. Topsoil $\mathrm{C}$ has a very weak negative correlation with normalised GNA ( $r=0.159 ; p=0.588$; Table 6$)$. Soil $\mathrm{pH}$ $(\mathrm{KCl})$ has the weakest influence of the three variables used in the best subset multiple regression. Its effect is thus probably masked by other factors when looking at correlation coefficients in Table 6. Very low $\mathrm{pH}$ conditions are known from the literature to inhibit microbial action and $\mathrm{N}$ mineralisation (Mariano et al. 2013), and this may play a role in our sample set. The relative yield response to fertilisation can now be predicted from the equation:

Relative yield $=-0.328131 *$ normalised GNA $-0.050457 *$ topsoil $\mathrm{C}-0.162507 * \mathrm{pH}(\mathrm{KCl})$

$$
+1.606912\left[n=14 ; R^{2}=0.751 ; F(3,10)=10.051 ; p<0.0023\right]
$$

Combining the predicted relative volume growth response with an estimate of potential volume growth at mid rotation for that site (e.g. using site index values) in a decision support system will yield volume response estimates that are useful in the prediction of operational 
profitability as postulated by Knott et al. (1996) and du Toit (2006).

\section{Conclusions}

In the Cape Forest Regions, almost all pine plantation forests respond to $\mathrm{P}$ fertiliser, but only some sites show further (significant) growth improvements when $\mathrm{N}$ fertiliser is added to the $\mathrm{P}$ supplements. We tried to predict stand responsiveness to added $\mathrm{N}$ fertiliser by investigating $\mathrm{N}$ mineralisation rates under pine stands in the Cape Forest Regions: it appears that a complex combination of soil characteristics (rather than particular, individual soil properties routinely measured in South African laboratories) collectively govern $\mathrm{N}$ mineralisation rates. Using multiple regression, we can predict relative yield improvement with fertilisation estimates that has a strong, significant relationship $\left(\mathrm{R}^{2}\right.$ of 0.751 ) with the observed relative yield. The normalised GNA (i.e. an estimate of the dynamic rate of available $\mathrm{N}$ supply or $\mathrm{N}$ flux) has the biggest leverage on the prediction equation. We can therefore accept the hypothesis formulated in Sect. 1, because normalised estimates of $\mathrm{N}$ availability based on incubation studies are indeed superior predictors of site responsiveness to added $\mathrm{N}$ fertiliser (in the presence of P) for the Cape Forest Regions. While the aerobic incubation techniques are a little more complicated and cumbersome than routine soil chemical analyses, it has great potential for use in a fertiliser decision support system to predict responsiveness to applied $\mathrm{N}$ fertiliser.

Acknowledgements We thank Vavariro Chikumbu, Phillip Fischer, Ilse Botman, Mark Februarie, Nele Bergmans, Louisa Erasmus, Deon Malherbe, Hugo Lambrechts and Anton Kunneke (all affiliated to Stellenbosch University at the time of their contribution) for technical assistance with fertiliser trial site selection, establishment, measurement, data curation as well as technical assistance on soil incubation studies. We also thank MTO forestry for assisting us to conduct the experiments in their forests.

Funding information This study was co-funded by MTO Forestry, Wild Peach Investment Holdings and the THRIP Programme of the National Research Foundation (South Africa), grant number TP 1207122754X.

Data availability The datasets generated and/or analyzed during the current study are available in the SUNScholarData repository, https:// scholardata.sun.ac.za/ https://doi.org/10.25413/sun.c.4824126.

\section{Compliance with ethical standards}

Conflict of interest The authors declare that they have no conflict of interest.

\section{References}

Albaugh TJ, Allen LH, Dougherty PM, Kress LW, King JS (1998) Leaf area and above- and belowground growth response of loblolly pine to nutrient and water additions. For Sci 44(2):317-328

Albaugh TJ, Allen HL, Dougherty PM, Johnsen KH (2004) Long term growth responses of loblolly pine to optimal nutrient and water resource availability. For Ecol Manag 192:3-19

Arslan H, Güleryüz G, Kirmizi S (2010) Nitrogen mineralisation in the soil of indigenous oak and pine plantation forests in a Mediterranean environment. Eur J Soil Biol 46:11-17

Binkley D, Vitousek P (1989) Soil nutrient availability. In: Pearcey R, Mooney HA, Rundel PW (eds) Plant Physiological Ecology: Field methods and instrumentation. Chapman and Hall, New York and London, pp 75-96

Binkley D, Hart SC (1989) The components of nitrogen availability assessments in forest soils. Advances in Soil Sciences 10:57-112

Bredenkamp BV (2012) The volume and mass of logs and standing trees. In: Bredenkamp BV, Upfold SJ (eds) South African forestry handbook, 5th edn. South African Institute for Forestry, Menlo Park, pp 239-263

Bremner JM (1965) Nitrogen availability indexes. In: Black CA (ed) Methods of soil analysis, Part. 2: Chemical and microbial properties. American Society of Agronomy, Madison, pp 1324-1345

Campion JM, du Toit B (2003) Updated recommendations for fertilisation of pine species in the summer rainfall region of southern Africa. ICFR Bulletin Series 18/2003 Institute for Commercial Forestry Research. Pietermaritzburg South Africa, pp 25.

Campoe OC, Stape JL, Albaugh TJ, Allen HL, Fox TR, Rubilar R, Binkley D (2013) Fertilisation and irrigation effects on tree level aboveground net primary production, light interception and light use efficiency in a loblolly pine plantation. For Ecol Manag 288: 43-48

Carlson CA, Soko S (2000) Impacts of fertilizer applied at first thinning to basal area growth of $P$. patula in the Mpumalanga area. ICFR Bulletin Series 11/2000. Institute for Commercial Forestry Research, Pietermaritzburg South Africa, pp 32.

Carlyle JC, Nambiar EKS, Bligh MW (1998) The use if laboratory measurements to predict nitrogen mineralization and nitrification in Pinus radiata plantations after harvesting. Can J For Res 28:12131221

Chen JM, Cihlar J (1995) Plant canopy gap-size analysis theory for improving optical measurements of leaf-area index. Appl Opt 34(27): $6211-6222$

Chikumbu V (2011) Growth responses to fertiliser application of thinned, mid-rotation P. radiata stands across a soil water availability gradient in the Boland area of the Western Cape. MSc thesis. University of Stellenbosch, South Africa, pp 174

De Ronde C (1992) The impacts of management on nutrient cycling in plantation forestry in the Southern Cape. PhD dissertation, University of Stellenbosch, South Africa, pp 208

Donald DGM, Lange PW, Schutz CJ, Morris AR (1987) The application of fertilizers to pines in southern Africa. South Afr For J 141:53-62

Dovey SB, du Toit B (2006) Calibration of LAI-2000 canopy analyser with leaf area index in a young eucalypt stand. Trees Struct Funct 20(3):273-277

Dovey SB, du Toit B (2015) Nitrogen mineralisation in a clonal Eucalyptus plantation on sandy soil after clearfelling and residue burning. Indian Forester 141(4):411-421

Dovey SB, de Clercq W, du Toit B (2011) A comparison of soil moisture relations between standing and clearfelled plots with burnt and unburnt harvest residue treatments of a clonal eucalypt plantation on the Zululand Coastal Plain, South Africa. Water SA 37(4):483-494 
Dovey SB, du Toit B, de Clercq W (2014) Nutrient leaching under zero tension in a subtropical clonal Eucalypt plantation on a sandy soil in South Africa. S Afr J Plant Soil 31(3):153-162

$\mathrm{du}$ Toit B, Scholes MC (2002) Nutritional sustainability of Eucalyptus plantations: A case study at Karkloof, South Africa. South Afr For J 195:63-72

du Toit B (2006) Information requirements to fertilize plantations with greater precision in a dry country. In: Ackerman PA, Längen DW, Antonides MC (eds) Precision Forestry in plantations, semi-natural and natural forests. Proceedings of the International Precision Forestry Symposium. Stellenbosch University, Stellenbosch, pp 245-260

du Toit B, Dovey SB (2005) Effect of site management on leaf area, biomass development and stand growth efficiency of a young stand of Eucalyptus grandis in South Africa. Can J For Res 35(4):891900

du Toit B, Scheepers GP (2020) Modelling soil nitrogen mineralisation in semi-mature pine stands of South Africa to identify nutritional limitations and to predict potential responses to fertilisation. V1. SUNScholarData. [Dataset]. https://scholardata.sun.ac.za/ https:// doi.org/10.25413/sun.c. 4824126

Fey M (2010) Soils of South Africa. Their distribution, properties, classification, genesis, use and environmental significance. Cambridge University Press, Cambridge

Fife DN, Nambiar EKS (1997) Changes in the canopy and growth of Pinus radiata in response to nitrogen supply. For Ecol Manag 93: $137-152$

Fischer PM, du Toit B (2019) Use of $\delta^{13} \mathrm{C}$ as water stress indicator and potential silvicultural decision support tool in Pinus radiata stand management in South Africa. iForests: Biogeosciences and Forestry 12:51-60

Fisher RF, Binkley D (2000) Ecology and management of forest soils, Chapter 13. Wiley, New York, p 489

Fox T, Allen H, Albaugh T, Rubilar R, Carlson C (2007) Tree nutrition and forest fertilisation of pine plantations in the southern United States. South J Appl For 31:5-11

Gower ST, Norman J (1991) Rapid estimation of leaf area index in conifer and broad-leaf plantations. Ecology 72(5):1896-1900

Hamonts K, Clough TJ, Stewart A, Clinton PW, Richardson AE, Wakelin SA, O'Callaghan M, Condron LM (2013) Effect of nitrogen and waterlogging on denitrifier gene abundance community structure and activity in the rhizosphere of wheat. FEMS Microbiol Ecol 83:568-584

Knoepp JD, Swank WT (1998) Rates of nitrogen mineralisation across an elevation and vegetation gradient in the southern Appalachians. Plant Soil 204:235-241

Knott JH, Turner J, Lambert MJ (1996) Fertilization of Pinus radiata plantations after thinning. II investment potential. Aust For 59(1): $22-31$

Kotze H, du Toit B (2012) Silviculture of industrial pine plantations in Southern Africa. In: Bredenkamp BV, Upfold S (eds) South African forestry handbook, Fifth edn. Southern African Institute of Forestry, Pretoria, pp 123-139

Laclau J-P, Ranger J, Gonçalves JLM, Maquère V, Krusche AV, M'Bou AT, Nouvellon Y, Saint-Andre L, Bouillet J-P, Piccolo MdC, Deleporte P (2010) Biogeochemical cycles of nutrients in tropical eucalyptus plantations. Main features shown by intensive monitoring in congo and brazil. For Ecol Manag 259(9): 1771-1785

Lee K-H, Jose S (2006) Nitrogen mineralisation in short-rotation tree plantation along a soil nitrogen gradient. Can J For Res 36:12361242

Lopes DM, Walford N, Viana H, Sette CR Jnr (2016) A proposed methodology for the correction of the leaf area index measured with a ceptometer for Pinus and Eucalyptus forests. Revista Arvore 40(5): $845-854$

Mariano E, Trivelin PCO, Leite JM, Megda MXV, Otto R, Franco HCJ (2013) Incubation methods for assessing mineralisable nitrogen in soils under sugarcane. Rev Bras Ciênc Solo 37:450-461

Morris AR (1995) Forest floor accumulation, nutrition and productivity of Pinus patula in the Usutu Forest, Swaziland. Plant Soil 168-169: 271-278

O'Connel AM, Grove TS, Mendham D, Corbeels M, McMurtrie RF, Shammas K, Rance SJ (2004) Impacts of inter-rotation site management on nutrient stores and fluxes and growth of a eucalypt planation in Southwestern Australia. In: EKS N, Ranger J, Tiarks A, Toma $\mathrm{T}$ (eds) Site management and productivity in tropical planation forests: proceedings of workshops in Congo July 2001 and China February 2003. Center for International Forestry Research, Bogor, pp 77-91

Pajuste K, Frey J (2003) Nitrogen mineralisation in podzol soils under boreal Scots pine and Norway spruce stands. Plant Soil 257:237247

Paul KI, Polglase PJ, O'Connell AM, Carlyle JC, Smethurst PJ, Khanna PK (2002) Soil nitrogen availability predictor (SNAP): a simple model for predicting mineralisation of nitrogen in forest soils. Aust J Soil Res 40:1011-1026

Paul KI, Polglase PJ, O’Connel AM, Carlyle JC, Smethurst PJ, Khanna PK (2003) Defining the relation between soil water content and net nitrogen mineralisation. Eur J Soil Sci 54:39-47

Payn TW, De Ronde C, Grey DC (1988) Phosphate fertilisation of mature P. radiata stands. South Afr For J 147:26-31

Pulito AP, Gonçalves JLM, Smethurst PJ, Junior JCA, Alcarde Alvares C, Rocha JHT, Hübner A, de Moraes LF, Miranda AC, Kamogawa MY (2015) Available nitrogen and responses to nitrogen fertiliser in Brazilian eucalypt plantations on soils of contrasting texture. Forests 6:973-991

Saggar S, Hedley CB, Salt GJ (2001) Soil microbial biomass, metabolic quotient, and carbon and nitrogen mineralisation in 25-year-old Pinus radiata agroforestry regimes. Aust J Soil Res 39:491-504

Saxton KE, Rawls WJ, Romberger JS, Papendrick RI (1986) Estimating generalized soil water characteristics from texture. Soil Sci Soc Am J 50:1031-1036

Scheepers GP (2018) Fertilisation of semi-mature Pinus elliottii and Pinus elliottii $x$ caribaea stands on a climatic gradient in the Tsitsikamma and its effect on system nutrition and stand productivity. PhD dissertation, Stellenbosch University, South Africa, pp 170

Sirivedhin T, Gray KA (2006) Factors affecting denitrification rates in experimental wetlands: field and laboratory studies. Ecol Eng 26: 167-181

Smethurst PJ, Gonçalves JLM, Pulito AP, Gomes S, Paul K, Alvares CA, Júnior JCA (2015) Appraisal of the SNAP model for predicting nitrogen mineralisation in tropical soils under Eucalyptus. Braz J Soil Sci 39:523-532

Tecimen HB, Kavgaci A (2011) Evaluation of net nitrogen mineralization rates at Pinus brutia ten. Forests and maquis shrublands in Southern Turkey. Fresenius Environ Bull 20(2):385-390

Turner J, Knott JH, Lambert M (1996) Fertilization of Pinus radiata plantations after thinning. I. Productivity gains. Aust For 59:7-21

Vitousek PM, Gosz JR, Grier CC, Melillo JM, Reiners WA (1982) A comparative analysis of potential nitrification and nitrate mobility in forest ecosystems. Ecol Monogr 52:155-177

Vose JM, Allen HL (1988) Leaf area, stemwood growth, and nutrition relationships in loblolly pine. For Sci 34:547-563

Publisher's note Springer Nature remains neutral with regard to jurisdictional claims in published maps and institutional affiliations. 